\title{
Molecular detection of goat and sheep meat origin using mitochondrial
} cytochrome b gene

\author{
Jahura $\mathrm{FT}^{1}$, Munira $\mathrm{S}^{1}$, Bhuiyan $\mathrm{AKFH}^{1}$, Hoque $\mathrm{MR}^{2}$, Bhuiyan $\mathrm{MSA}^{1 *}$ \\ ${ }^{1}$ Department of Animal Breeding and Genetics, Bangladesh Agricultural University, Mymensingh-2202; ${ }^{2}$ Genet \\ Bio Inc., Yuseong-gu, Daejeon 305-500, Republic of Korea
}

\begin{abstract}
The present study was conducted to discriminate between sheep and goat species meat origin utilizing mitochondrial cytochrome $\mathrm{b}(\mathrm{Cyt} b)$ gene fragment. A total of 46 ear tissue and meat samples were collected from different slaughterhouses and farms of Mymensingh and Rangpur districts. Genomic DNA was extracted using GeNet Bio DNA isolation kit and DNA concentration and purity was quantified by NanoDrop spectrophotometer. Two pairs species specific primer were used to amplify Cyt $b$ gene fragments. Selected primers were highly conserved across the breed within a species and worked well with the species of indigenous goat and sheep resulting similar size of the amplicons 330 and 585 bp respectively. The duplex PCR condition would enable to detect adulteration from goat and sheep mixed samples which revealed by two precise bands (330 and $585 \mathrm{bp}$ ) in a single reaction. This study suggests an accurate molecular technique for identification of sheep and goat meat species origin and differentiates species present in adulterate meat samples. In conclusion, this DNA based marker could be used for prevention of fraudulent practice in slaughterhouse and chain shops in Bangladesh.
\end{abstract}

Key words: goat, sheep, cytochrome b gene, PCR, agarose gel

Bangladesh Animal Husbandry Association. All rights reserved.

Bang. J. Anim. Sci. 2016. 45 (2): 41-45

\section{Introduction}

Goat meat or chevon is the most popular red meat in Bangladesh. Chevon stands second in position among the produced red meat in Bangladesh which has been widely used in different festivals (). Consumers prefer goat meat for its better taste, texture and flavour. On the other hand, sheep meats (mutton) are generally not popular to the consumers of Bangladesh due to its characteristic odour. Therefore, price of chevon is about double than mutton. Goat and sheep population in Bangladesh is currently estimated to comprise 25.73 million goats and 3.21 million sheep (BER, 2015). Although a considerable number of sheep populations are available in Bangladesh, but there is no butcher shop or slaughterhouse who sell sheep meat in the market. In most cases, sheep are slaughtered by goat butcher and sold as chevon to the consumers. Moreover, adulteration may take place in the form of substitution of one cheaper meat with a costly expected species in value added products (Malmheden and Emanuelsson, 1998).

*Corresponding author: bhuiyansa@yahoo.com
However, consumer faces unhealthy competition in meat market not protected from these malicious practices of meat adulterations. Meat adulteration and mislabelling are illegal and raise many healths, religious and economic issues. The detection of adulterations and identification of adulterants in meat products is important for the implementation of national standards as well as to protect the consumer preference (Haider et al., 2012). Different DNA-based techniques have been used for animal species identification for the last two decades. Utilization of polymerase chain reaction of mitochondrial DNA (mtDNA) is modern method of animal species identification. The large variability of mtDNA targets as compared with nuclear sequences facilitates the discrimination of closely related animal species even in the case of mixture of species (Prado et al., 2002).Genes to be targeted in mtDNA for amplification could be 12S, $16 \mathrm{~S}$ and 18SrRNA, actin, cytochrome b, cytochrome oxidase-II, NADH dehydrogenase $5 / 6$ and mtDNA D-loop (Kesmen et al., 2009). In present study forward and reverse primers were selected from a published paper of Zarringhabaie et al. (2011) who used to amplify the fragment of $C y t b$ gene 
for goat and sheep species origin identification. The advantage of PCR based tests are higher accuracy, time saving, high sensitivity and flexibility compared to other methods (Amjadi et al., 2012). Despite, the PCR based techniques have been used in developed worlds as well as in neighbouring countries to protect malpractice in slaughterhouses as well as in super markets but this kind of molecular approaches are totally absent in Bangladesh. Therefore, the objectives of this study were to adopt PCR based technique and to develop DNA marker from $C y t b$ gene for identification of goat and sheep species meat origin and detection of adulteration from mixed samples.

\section{Materials and Methods}

\section{Sample collection, transportation and processing}

Forty-six (46) ear tissue or meat samples of goat and sheep were collected from different regions of Mymensingh and Rangpur districts. Samples collected for this study purpose were submersedinto $96 \%$ alcohol immediately after collection and transferred to the Animal Genetics Lab, Bangladesh Agricultural University, Mymensingh and stored at room temperature into a small plastic tube.

\section{DNA extraction and quantification}

Samples were trimmed to remove extra hair root and exogenous fat before DNA extraction. DNA was extracted according to the instructions followed by the GeNet Bio genomic DNA isolation kit.DNA concentration was assessed by $0.8 \% \mathrm{gel}$ electrophoresis as well as NanoDrop spectrophotometer (Model ND1000). Purity of extracted DNA was assessed by calculating the OD260/OD280 $\mathrm{nm}$ ratios using NanoDrop (Model ND1000) spectrophotometer. Selected DNA samples were homogenised with a concentration of $\sim 50 \mathrm{ng} / \mu \mathrm{l}$ by adding $\mathrm{ddH}_{2} \mathrm{O}$ and stored at $20^{\circ} \mathrm{C}$ for further studies.

\section{Cyt $b$ gene amplification by single and duplex PCR}

The primer sequence information was obtained from a published paper by Zarringhabaie et al. (2011). The Cytb gene sequence of Black Bengal goat and indigenous sheep were retrieved from NCBI gene bank data base (accession no. $A B 110597.1$ and $A B 006800.1$ ) and were aligned by CLUSTAL OMEGA software (EMBL lab) to check the suitability of selected primers for indigenous sheep and goat species of Bangladesh. Two sets of primer pairs which were used for PCR amplification are listed in the Table 1. PCR amplification was performed by using gradient thermocycler (Biometra). Two types of PCR reaction was carried out which are given below:

\section{i) Cyt b gene amplification by single PCR}

PCR reaction was carried out in $20 \mu$ volume comprising of $1 \mathrm{X}$ buffer, $1.5 \mathrm{mM} \mathrm{MgCl}, 0.2 \mathrm{mM}$ dNTP, $1.0 \mu \mathrm{M}$ of each primer, $2 \mu \mathrm{l}$ ( 50ng/ $\mu$ l)of genomic DNA and $0.3 \mathrm{U}$ Taq DNA polymerase.

\section{ii) Cyt b gene amplification by duplex PCR}

Duplex PCR means both forward and reverse primers were added in mixed samples in one PCR reaction. PCR reaction was carried out in $20 \mu \mathrm{l}$ volume comprising of $1 \mathrm{X}$ buffer, $1.5 \mathrm{mM} \mathrm{MgCl}$, $0.2 \mathrm{mM} \mathrm{dNTP}, 1.5 \mu \mathrm{M}$ of each primer, 3 $(1.5+1.5) \mu \mathrm{l}(\sim 50 \mathrm{ng} / \mu \mathrm{l})$ of mixed genomic DNA and $0.5 \mathrm{U}$ Taq DNA polymerase. The PCR amplification was performed using Biometra thermo-cycler and cyclic conditions comprised of initial denaturation for $10 \mathrm{~min}$ at $94^{\circ} \mathrm{C}$, followed by 35 cycles of denaturation for $30 \mathrm{~s}$ at $94^{\circ} \mathrm{C}$, annealing at $62^{\circ} \mathrm{C}$ for $60 \mathrm{~s}$, extension at $72^{\circ} \mathrm{C}$ for $45 \mathrm{~s}$, and a final extension at $72^{\circ} \mathrm{C}$ for $10 \mathrm{~min}$.

Table 1. Two sets of primer pairs used for PCR amplification

\begin{tabular}{llll}
\hline Species & Type & Primer sequence & Reference \\
\hline Goat & Forward & CGCCATGCTACTAATTCTTGTT & \\
& Reverse & TGTCCTCCAATTCATGTGAGTGT & Zarringhabaie et al. (2011) \\
Sheep & Forward & TACCAACCTCCTTTCAGCAATT & \\
& Reverse & TGTCCTCCAATTCATGTGAGTGT & \\
\hline
\end{tabular}




\section{Agarose gel documentation of PCR product}

The PCR products were electrophoresed at $120 \mathrm{~V}$ for $25 \mathrm{~min}$ in $2.0 \%$ agarose gels. For this, $0.5 \mathrm{x}$ TBE buffer solution was used to prepare $2.0 \%$ gel which stained with $5 \mu \mathrm{l}(10 \mu \mathrm{g} / \mu \mathrm{l})$ of ethidiumbromide (BioNEER, SouthKorea). The gel images were documented by UVsolo TS imaging system (Biometra, Germany).

\section{Results and Discussion}

\section{DNA concentration and purity}

The concentration and purity of extracted DNA is presented in Table 2. Purity of extracted DNA ranged from 1.82 to 1.93 in case of sheep and 1.83 to 1.95 in case of goat samples. TheDNA concentration ranged from 74 to $700 \mathrm{ng} / \mu \mathrm{l}$ in case of sheep samples and 43 to $644 \mathrm{ng} / \mathrm{\mu l}$ in case of goat samples extracted from ear tissue but very low concentration was found for meat tissue samples which ranged from 11 to $24 \mathrm{ng} / \mu \mathrm{l}$ in case of sheep and 25 to $58 \mathrm{ng} / \mu \mathrm{l}$ in case of goat. Therefore, it is postulated that extraction methods need to optimise particularly for the amount of digestion enzyme (proteinase K)utilizing meat tissue samples by commercial genomic DNA extraction kit. In addition, the variation in concentration of extracted DNA might be due to differences in extraction methods, sources of sample and individual efficiency.

However, the amount of extracted DNA would be sufficient for PCR amplification and standardization of all samples were performed before heading to further amplification process. Tataurov et al. (2008) reported the concentration of DNA varied from 50 to $1410 \mu \mathrm{g} / \mathrm{ml}$ extracted from blood and meat products (meatballs) which are within the range of the present study. Satish et al. (2009) measured DNA concentration from the cooked meat samples of ruminant and poultry species which ranged from 20 to $100 \mu \mathrm{g} / 500$ $\mathrm{mg}$, which was much lower than that of raw meats (100 $\mathrm{\mu g}$ to $500 \mu \mathrm{g} / 500 \mathrm{mg}$ ) of same species as well as from the concentration of the present study. The samples having optical density (OD) ratio at 260/280 ranged between 1.7 to1.9 and not showing smearing on agarose gel electrophoresis were included for further reactions (Satish et al., 2009). In this study the minimum purity of extracted DNA was 1.82 which revealed that all the DNA samples were supposed to be free of proteins and RNA and suitable for PCR based study.
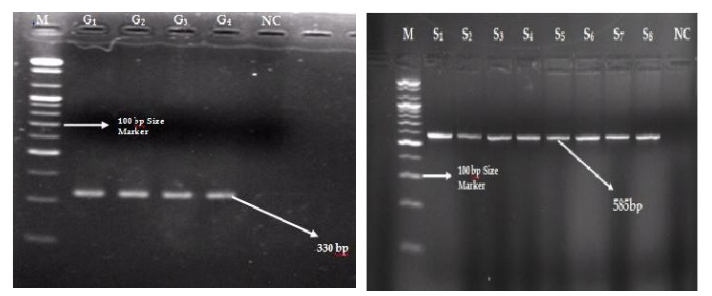

Figure 1. Agarose gel electrophoresis of single PCR amplification using Cyt $b$ gene fragment for goat and sheep shown in $2.0 \%$ agarose gel. 330 bp and 585 bp for goat species specific band, $M=100$ bp DNA size marker, $\mathrm{NC}=$ negative control and $\mathrm{G} 1-\mathrm{G} 4=$ goat samples, $\mathrm{S} 1-$ S8=sheep samples.

\section{Cyt b gene amplification by PCR}

\section{Cyt b gene amplification by single PCR for species specific detection}

Initially, independent primers were run using a pair of species-specific forward primer and reverse primers (common for two species). In 20 $\mu \mathrm{l}$ reaction volume, $1.0 \mu \mathrm{M}$ of each primer was used in single PCR and $2.0 \mu \mathrm{l}$ genomic DNA mixed with $18.0 \mu \mathrm{l}$ PCR master mix.

Table 2. Summary of concentration and purity value of extracted DNA

\begin{tabular}{|c|c|c|c|c|c|c|c|}
\hline \multicolumn{2}{|c|}{ Ear tissue and meat samples } & \multicolumn{3}{|c|}{$\begin{array}{l}\text { Concentration of extracted DNA } \\
\qquad(\mathrm{ng} / \mu \mathrm{l})\end{array}$} & \multicolumn{3}{|c|}{ Purity of extracted DNA } \\
\hline & & Max & Min & Average & Max & Min & Average \\
\hline \multirow[t]{2}{*}{ Ear tissue } & Goat $(n=20)$ & 643.4 & 43.70 & 203.39 & 1.95 & 1.83 & 1.88 \\
\hline & Sheep $(n=16)$ & 869.7 & 74.80 & 338.86 & 1.92 & 1.82 & 1.87 \\
\hline \multirow[t]{2}{*}{ Meat tissue } & Goat meat $(n=5)$ & 58.3 & 24.90 & 37.66 & 1.93 & 1.89 & 1.91 \\
\hline & Sheep meat $(\mathrm{n}=5)$ & 24.4 & 11.10 & 18.63 & 1.93 & 1.87 & 1.90 \\
\hline
\end{tabular}




\section{Cyt b gene in small ruminant meat origin}

The results showed expected different species specific amplified PCR product sizes of 330 and 585 bps for $C y t b$ gene fragment of goat and sheep species, respectively (Figure 1 ) for pure meat and ear tissue sample of those species. The exact fragment size was reported by Zaringabaie et al., (2011) using sheep and goat meat samples of Iranian origin. The features revealed that selected primer sequence is highly conserved among the breeds of same species and could be utilized efficiently in Bangladeshi sheep and goat population.

\section{Cyt b gene amplification by duplex PCR for detection of adulteration in mixed meat samples}

Having confirmed species specificity of each primer independently, a duplex PCR was standardized by mixing all primers in a single reaction but targeting DNA of single species. Electrophoresis band pattern of PCR amplicon on $2.0 \%$ agarose gel resulted clear cut differentiation between goat (330 bp) and sheep (585 bp) when run with single species and multiple band pattern (330 and $585 \mathrm{bp}$ ) when run with mixed DNA samples of goat and sheep (Figure 2). In that case, duplex PCR was optimised by changing the concentration of each primer $(1.5 \mu \mathrm{M})$, genomic DNA $(1.5 \mu \mathrm{l}$ for each species) and polymerase enzyme $(0.5 \mathrm{U} /$ reaction). This result revealed that selected primers worked well in duplex manner and discriminate sufficiently the species meat origin from the mixed samples.

This method is sensitive and is possible to trace each species meat from adulterate samples. The amplicon sizes resulted by duplex PCR using mtDNA $C y t b$ gene for goat and sheep species in $2 \%$ agarose gel are shown in Figure 2. Several studies were conducted on molecular traceability of species origin from the samples of meat and meat products using mitochondrial $C y t b$ gene where they employed different molecular methods like PCR, PCR-PFLP, PCR-SSR, Real time $P C R$ and FINS. All of these methods traced species origin and adulteration in meat and meat products efficiently. For example, Zarringhabaie et al. (2011) reported different specific amplified fragments of pure meat sources for buffalo (124 bp), goat (330 bp), cattle (472 bp) and sheep (585 bp) species and this method was able to trace less than $10 \%$ of the other species of meat in the mixture. This finding conforms to this present investigation where similar amplicon sizes were found.

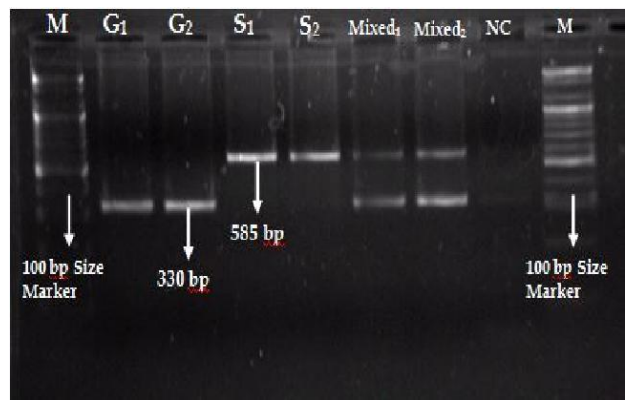

Figure 2. Agarose gel electrophoresis of amplicon by duplex PCR using mtDNA Cyt $b$ gene for goat and sheep species. Here $\mathrm{M}=100$ bp DNA size marker, G1-G2 for goat and S1-S2 for sheep samples. Mixed samples contain sheep and goat DNA with equal proportion. Electrophoresis was done in $2.0 \%$ agarose gel and specific amplified product sizes 330 and 585 bp for Cyt $\mathrm{b}$ gene fragment of goat and sheep respectively, $\mathrm{NC}=$ negative control.

In another investigation, Satish et al. (2009) worked on mitochondrial $C y t b$ gene based PCR to identify and differentiate species from the cooked meat of sheep, goat, cattle, pig and chicken. These animal species produced DNA fragments of 331, 157, 274, 398 and 227 base pairs respectively and clearly differentiated the species origin of meat. The amplified fragments were different from the present study as they used different primer sets of Cyt $b$ gene. The use of PCR techniques to amplify the mitochondrial Cyt $b$ gene in identifying pig DNA in foods has been reported by several authors (Chandrika et al., 2009; Tanabi et al., 2007). Nuraini et al. (2011) used Cyt $b$ gene and detected the presence of rat meat in a mixture of beef meatballs at concentration of $15 \%$ which was labelled as $100 \%$ beef originated. Buffalo, cattle, goat and sheep species also detected on mitochondrial Cyt $b$ based on PCR-RFLP methods (Ahmed et al., 2005; Zahran et al., 2015). Amjadi et al. (2012) used PCR-RFLP technique in mitochondrial Cyt $b$ gene and detected $80 \%$ of the collected samples were contaminated by prohibited ruminant residuals. Species identification using PCR-RFLP of a mitochondrial $C y t b$ segment has been well documented (Partis et al., 2000). 
All above discussions revealed that Cyt $b$ gene is a widely used marker for meat species identification and detection of adulteration from mixed meat samples and also support our study. Single and duplex PCR in mitochondrial $C y t b$ gene used in this study is an easier method then PCR-RFLP, PCR-SSR, PCR-FINS and Real time $P C R$. The advantage of the present molecular methods is that there is no need to use restriction enzyme and RFLP methods to distinguish specific electrophoresis fragment on agarose gel and the post PCR analysis is much simpler than other methods. Also, this PCR based method is reliable, highly sensitive and specific, as well as cost effective and less time consuming.

\section{Conclusion}

Our DNA based study showed an accurate analytical technique for identification of goat and

\section{References}

Ahmed M, Mezawy EA (2005). Detection of speciesspecific genetic markers in farm animals by RFLP analysis of cytochrome $b$ gene. Biotechnology in Animal Husbandry, 21: 1-11.

Amjadi $\mathrm{H}$, Varidi MJ, Marashi $\mathrm{SH}$, Javadmanesh $\mathrm{A}$, Ghovvati S (2012). Development of rapid PCRRFLP technique for identification of sheep, cattle and goat's species and fraud detection in Iranian commercial meat products. African Journal of Biotechnology, 11: 8594-8599.

Bangladesh Economic Review (2015). Finance Division, Ministry of Finance Government of the People's Republic of Bangladesh. 93

Chandrika M, Zainon MN, Maimunah M, Lesley MB, Jinap S, Son R (2009). Meat species identification and halal authentication analysis using mitochondrial DNA. Journal of Meat Science, 83: 57-61.

Haider N, Imad N, Bassam A (2012). Identification of meat species by PCR-RFLP of the mitochondrial COI gene. Journal of Meat Science, 90: 490-493.

Kesmen Z, Gulluce A, Sahin F, Yetim H (2009). Identification of meat species by TaqMan based real-time PCR assay. Journal of Meat Science, 82: 444-449.

Malmheden YI, Emanuelsson R (1998). New technology for faster disclosure of meat adulteration. Var Fada(in Swedish), 3:6-7.

Nuraini $H$, Primasari A, Andreas E, Sumantri C (2011). The Use of Cytochrome b Gene as a Specific Marker of the Rat Meat (Rattus sheep species meat origin by conventional PCR and meat adulteration between these two species through duplex PCR analysis without further using any enzymatic digestion. Therefore, it can be suggested as a useful laboratory tool especially for meat traceability and has also commercial impact for prevention of malpractice in slaughterhouse, meat products factory and chain shops of Bangladesh.

\section{Acknowledgement}

The authors gratefully acknowledge University Grant Commission (UGC) for financial support and Department of Animal Breeding and Genetics, Department of Microbiology and Hygiene, Bangladesh Agricultural University (BAU), Mymensingh for providing necessary facilities to accomplish this research.

norvegicus) on Meat and Meat Products. Media Peternakan, 15-20.

Partis L, Croan D, Guo Z, Clark R, Coldham T, Murby J (2000). Evaluation of a DNA fingerprinting method for determining the species origin of meats. Journal of Meat Science, 54: 369-376.

Prado M, Franco CM, Fente CA, Cepeda A, Vazquez BI, Velazquez JB (2002). Comparison of extraction methods for the recovery, amplification and species-specific analysis of DNA from bone and bone meals. Electrophoresis,23: 1005-1012.

Satish, Kumar A, Singh $Y$, Minakshp, Prasad G (2009). Cytochrome- b gene based PCR for identification and differentiation of cooked meat of sheep, goat, cattle, pig and poultry. Journal of Haryana Veterinary, 48: 53-57.

Tanabe E, Miyauchi A, Muneshige K, Sato MC, Sato $M$ (2007). PCR method of detecting pork in foods for verifying allergen labelling and for identifying hidden pork ingredients in processed foods. Bioscience Biotechnology Biochemistry, 71: 1663-1667.

Tataurov AV, You Y, Owczarzy (2008). Predicting ultraviolet spectrum of single stranded and double stranded deoxyribonucleic acids. Biophysics Chemistry,133: 66-70.

Zahran D, Hagag S (2015). Use of molecular biology techniques in the detection of fraud meat in the Egyptian market. African Journal of Biotechnology, 14: 360-364.

Zarringhabaie GE, Pirany N, Javanmard A (2011). Molecular traceability of the species origin of meats using multiplex PCR. African Journal of Biotechnology, 10: 15461-16465. 